\title{
Gaps in the IFRS Conceptual Framework
}

\author{
Richard Barker ${ }^{1}$ and Alan Teixeira ${ }^{2}$
}

\begin{abstract}
The stated purpose of the IFRS Conceptual Framework is to assist the IASB to develop Standards that are based on consistent concepts, and also to assist preparers to develop consistent accounting policies when Standards either do not apply or allow a choice of accounting policy. Yet, the Framework actually does surprisingly little to help the IASB (or preparers) determine which assets, liabilities, income and expenses should be recognised, and how they should be measured. The Framework's focus on assets and liabilities implies that the accounting can, and should, be determined from the balance sheet. Yet, many current financial reporting requirements focus initially on the income statement, and so they are not so much derived from the Framework as instead in need of being reconciled back to it. At its heart, the problem here is that, while the Framework states that accrual accounting provides a better basis for assessing past and future performance than cash-based information, it does not explain why. To do so would require a conceptualisation of how entities' business models are employed to create value, and of the strengths and limitations of accounting data in enhancing investors' understanding of that valuecreation. The lack of explanation of the purpose and informational objectives of accruals, how they relate to business models and how they cause the income statement and the balance sheet to interact are gaps in the Framework. Filling those gaps would provide a more robust, and natural, way for the IASB to develop recognition and measurement requirements in its Standards.
\end{abstract}

This paper has benefited from comments from two anonymous referees and members of the UK Financial Reporting Council's Academic Panel.

\footnotetext{
${ }^{1}$ Professor of Accounting, Saïd Business School, Oxford University, richard.barker@sbs.ox.ac.uk

${ }^{2}$ Global Director of IFRS Research, Deloitte LLP and Adjunct Professor of Accounting, University of Auckland, alteixeira@deloitte.co.uk
} 


\section{The Framework's Objective of Financial Statements}

The IASB's Framework states that (IASB, 2018, para. 3.2) "the objective of financial statements is to provide information about an entity's assets, liabilities, equity, income and expenses that is useful to users of financial statements in assessing the prospects for future net cash inflows to the reporting entity and in assessing management's stewardship of the entity's economic resources." It is also made clear (para. 1.7) what the objective is not, namely that general purpose financial statements "are not designed to show the value of a reporting entity; but they provide information to help existing and potential investors, lenders and other creditors to estimate the value of the reporting entity."

Yet the Framework leaves open the question of what information is best able to help investors, lenders and other creditors estimate the value of the reporting entity. It is sufficiently unconstrained that it can accommodate either a "full fair value model", focused on the balance sheet, or a completely transaction-focused "historical cost" model. Consider, for example, that the Framework also makes the following statement (para. 5.7):

Not recognising an item that meets the definition of an element makes the statement of financial position and the statement(s) of financial performance less complete and can exclude useful information from financial statements.

In itself, this statement seems to imply that all assets and liabilities should be on the balance sheet. The gap between the price and book value of listed entities is sometimes cited as evidence of assets, particularly intangibles, being omitted from the balance sheet (Lev, Bharat and Sougiannis, 2005; Lev and $\mathrm{Gu}, 2016)$. The contribution that intangibles assets make to the S\&P 500 has grown from 17 per cent in 1975 to 84 per cent in 2015 (Ocean Tomo, 2016). Yet, at least in principle, the Framework calls for the recognition of various assets that attract much of this criticism, whether they have been developed internally or acquired from an external party. The primary exception can be characterised as goodwill, which is only recognised in a business combination.

When the FASB developed Concepts Statement 1, and gave primacy to assets and liabilities, it did not include anything about how assets or liabilities should be measured. It would be another four years before the FASB produced concepts on measurement. Yet, as noted by Storey and Storey (1998, pages 76-85) defining assets and liabilities as the primary elements "limits or restrains not only what can be included in in assets and liabilities but also on what can be included in income." For an item to meet the definition of income, or its components, it is necessary for there to be a corresponding change in assets or liabilities. The confusion between the conceptual construction of the elements and question of how they should be measured was a significant factor for the FASB in its deliberations.

The IASB has missed an opportunity to address that confusion. The Framework includes a new section on measurement, which sets out different bases for measuring assets and liabilities. Income is a measure of the increase in the net resources of the enterprise during a period, defined primarily 
in terms of increases in assets and decreases in liabilities (Bullen and Crook, 2005). Such an approach implies an assumption that a focus on asset (and liability) recognition and measurement is sufficient conceptually to meet the demand for usefulness, even though in practice this assumption appears not always to hold and thereby offers insufficient conceptual guidance.

To illustrate this open-ended nature of the Framework, consider a straightforward test, which is whether the Framework can deal with simple issues. Inventory and property, plant and equipment (PP\&E) are simple and pervasive cases. Yet, our assessment is that if the IASB takes its Framework and develops requirements for these items from first principles, it is difficult to see what accounting would result. In general, we argue that, at best, the Framework constrains the IASB (and practitioners) by limiting the accounting solutions. It is unlikely, however, to enable the IASB to determine when or which assets should be recognised or, in particular, how they should be measured; it appears that something conceptual is missing.

Moreover, there are several important conceptual themes that are implicit at the level of individual Standards yet are (largely) absent from the Framework. This suggests that conceptual issues are worked through at this (lower) level, rather than being guided by, and being consistent with, an overarching conceptual framework. In contrast, the primary purpose of an effective conceptual framework should be to assist the IASB to develop Standards, by means of the consistent application of an underlying logic. This ideal state is of course not easily attained. Yet there ought not to be demonstrable gaps in the IASB's Framework, because these would imply a degree of conceptual vagueness which undermines logical consistency; while it is unrealistic to presume that any conceptual framework could be perfect (Macve, 2010), it is nevertheless possible to identify ways in which the IASB's Framework could be better designed for purpose.

We acknowledge that the IASB's revisions to its Framework are a work in progress. The IASB has acknowledged that some sections of the Framework remain less developed than it would like. We agree, and this paper is intended as a contribution to that development.

\section{The Purpose of Accruals}

We argue that the ambiguity described above corresponds to an incomplete specification of the purpose of accrual accounting. The Framework provides little insight into the assumptions that underpin accrual accounting and why, given the investment and stewardship objectives of general purpose financial reports, there are presumed to be informational advantages that make accrual accounting a 'better' basis for assessing past and future performance than cash-based information 
(Barker and Penman, 2018). ${ }^{3}$ This is in spite of a focus, in almost all of the IASB's Standards, on how to apply accrual accounting.

Accruals are central in accounting. Recognising any asset, other than cash, is a consequence of applying accrual accounting. Measurement requirements are necessary only because of accrual accounting. In order to give greater practical clarity and foundation to the overarching objective of financial reporting, it is therefore necessary to reconcile it with the underlying mechanics of accrualbased double-entry. This gets to the heart of accounting policy, because there are different ways in which accrual accounting can depart from cash accounting, revealing different types of information or resolving different uncertainties. A conceptual framework should provide guidance on how to conceptualise accruals in order to measure transactions initially and in subsequent periods, which the IASB can then apply in its Standards.

Of course, over the life on an entity the cash flows and accruals will be identical, if the entity has clean-surplus accounting (Peasnell, 1982; Ohlson, 1991). Similarly, an entity's earnings and returns are equivalent over the life of the entity, and earnings explain most of an entity's returns over sufficiently long periods of time (Easton et al., 1992). ${ }^{4}$ Yet the distinctive informational content of accounting is periodic, and it is these limited time frames with which the IASB is concerned.

Accounting data provide information relevant to the forecasting of future cash flows (Sloan, 1996), but they are not themselves those forecasts. The question for accrual accounting is what aspects of the value creation process are periodic financial statements best able to reveal, and by means of which departures from cash accounting (Black, 1980).

Some accruals recognise transactions before the exchange of cash, or other assets, takes place. Purchases or sales can be recognised before payment is made or received, usually when the parties have agreed to make the exchange, such that the accrual reveals the existence of a pending cash flow; receivables and payables fall into this category. Some other accruals reveal information about investments made by the entity and then about the timing of consumption of associated economic benefits; as, for example, with inventory, or PP\&E. Still other accruals reveal changes in value, such as when a fair value gain or loss on an asset or liability is recognised.

In general, accruals either allocate a transaction price to one or more financial reporting periods or measure the related asset or liability at a current value. Accruals that allocate transaction price are

\footnotetext{
3 There is only a brief mention of accrual accounting in the Framework: Accrual accounting depicts the effects of transactions and other events and circumstances on a reporting entity's economic resources and claims in the periods in which those effects occur, even if the resulting cash receipts and payments occur in a different period. This is important because information about a reporting entity's economic resources and claims and changes in its economic resources and claims during a period provides a better basis for assessing the entity's past and future performance than information solely about cash receipts and payments during that period. (IASB, (2016), paragraph1.17)

${ }^{4}$ Easton et al suggest that earnings explain about 80 per cent of returns when both variables are measured over a 10 year window.
} 
typically characterised as historical cost accounting, while accruals that adjust the asset or liability to a current value are typically characterised as fair value, or balance sheet focused, accounting (Penman, 2007). The historical cost accruals generally do not purport to measure assets or liabilities at a particular value, such as an exchange, exit or replacement price. However, because of the conceptual primacy given to assets and liabilities those measures are only attached to balance sheet items that meet the asset and liability definitions. Standards that focus on historical cost accruals instead generally specify how to measure income or expense, with the measure of the related asset or liability being a consequence of that measurement (Sprouse, 1966; Basu and Waymire, 2010). In contrast, Standards that focus on current values specify how to measure the asset or liability, with the measure of the related income or expense being a consequence of that measurement.

\section{Insert Table 1 here}

Table 1 provides our assessment of how the current requirements in IFRS could be characterised on this basis. Standards that focus on income include revenue recognition and inventory. Standards that focus on the balance sheet include investment property and agriculture. Most Standards have mixed approaches. For example, IFRS 9 Financial Instruments requires some financial instruments to be accounted for at amortised cost, which focuses primarily on the income statement, and fair value for other financial instruments.

We argue that these different uses of accruals arise in practice in accounting standards for several reasons, which are not adequately explored in the Framework. The fundament question is when accruals should be based on the transaction price and when should they shift to current value.

\section{Accruals and Entity-Specific Business Models}

In guiding the application of accrual accounting, the primary omission from the Framework is an acknowledgement that, in practice, value can be created in different ways, through different 'business models', with the implication that users require information that has a degree of entityspecificity (Marshall and Lennard, 2016). ${ }^{5}$ This notion of a business model can be said to provide the underlying logic for an investor's valuation model, which in turn therefore provides the context for understanding ways in which investors look to the financial statements to provide input data into those models.

At present, however, the Framework does little to explore the purpose for which an entity undertakes a transaction. It implies that the business model could be helpful in selecting measurement attributes, but it does not say why or how. Nor does it consider the conditions under which transactions are assumed to be entered into, even though differences in those conditions are

\footnotetext{
${ }^{5}$ The invitation to comment on the exposure draft of the Conceptual Framework states that the IASB did "not include a general discussion on the role of a business model in financial reporting, but does discuss how the way in which an entity conducts its business activities may affect (a) the unit of account; (b) measurement; and (c) presentation and disclosure.
} 
consequential for the design of useful financial accounting information. These considerations are important because the user needs to understand the nature, purpose and context of the business activity in question.

The IASB acknowledged the role of the business model when it developed IFRS 9 Financial Instruments. The Basis for Conclusions to IFRS 9 states that "an entity's business model affects the predictive quality of contractual cash flows-i.e. whether the likely actual cash flows will result primarily from the collection of contractual cash flows." (BC4.15) The implied question here is how the business activities of the entity in the current period can best be captured, both to enable the evaluation of performance during the period and to provide a foundation for the extrapolation of future performance. It is not the current-period cash flows that matter, but instead how data about transactions and events can be structured as inputs for investors, for their valuation models and in making investment decisions under conditions of uncertainty (Barker and Penman, 2018). This question of the design of accrual accounting concerns both what financial statements are useful for and how accruals are implemented towards the goal of that end use.

To the extent that the Framework refers to how an asset or liability contributes to future cash flows, it restricts itself to focusing only on asset and liability measurement. The Framework therefore does not examine the potential information benefits of measuring income or expenses and allowing the related assets or liabilities to be measured as a consequence, even if those asset and liability measures do not correspond with a current value (Penman, 2009). The IASB's Framework states that a measurement basis "is an identified feature (for example, historical cost, fair value or fulfilment value) of an item being measured. Applying a measurement basis to an asset or a liability creates a measure for that asset or liability and for related income or expenses." ${ }^{6}$ The implication is that the Framework directs attention to measuring assets and liabilities, with income and expenses being only a consequence of this measurement. There is no discussion on measuring income or expenses directly, even though many of the IASB's Standards rely on measuring components of comprehensive income.

\section{Accruals in the Income statement}

To illustrate the limitations of the IASB's approach, consider the example of inventory, which is traditionally of course not measured at fair value. Instead, the generally accepted accounting practice that has survived for more than a century is that inventory is measured at the lower of cost or market value and is recognised as an expense when it is sold, or impaired (Basu and Waymire, 2006; Zimmerman and Bloom, 2016). ${ }^{7}$ Surprisingly, that accounting is not an obvious outcome of

\footnotetext{
${ }^{6}$ IASB (2018), paragraph 6.1

${ }^{7}$ The current value in IFRS is net realisable value. The current value in the FASB's requirements is replacement cost, although replacement cost should not exceed the net realisable value or be lower than net realisable value less a normal profit margin.
} 
the Framework, and it may be less obvious in the revised Framework. It is also different from the accounting for agricultural produce and investment properties, both of which use fair value for subsequent measurement. The implication is that something is missing from the principles guiding the IASB. It could be that the IFRS requirements are inconsistent or flawed. Or it could be, as we surmise, that the Framework is incomplete because it does not guide us naturally to these outcomes.

Inventory exists to be sold. This is the justification for IAS 2 Inventories being a Standard in the first place, the reason for inventory being a separate category on the balance sheet, and the (entityspecific) reason why an asset with specific, objective physical properties (such as an item of machinery) could be classified as inventory for one entity and as PP\&E for another. Yet, wishing to stay clear of adopting exit price (fair value) measurement, the IASB justifies continuation of a costbased approach on the grounds that "inventory typically cannot be sold to a customer, except by making extensive use of the entity's other economic resources (for example, in production and marketing activities)." ${ }^{8}$ This does not in itself justify the use of cost, even though it does give a reason why fair value might not be appropriate. There are examples where an IFRS requires fair value measurement even though selling the item arguably requires more of the entity's resources and production and marketing efforts than are required for inventory-for example, biological assets and non-current assets held for sale. This suggests, again, that the Framework is at best providing an incomplete conceptual foundation.

A more straightforward justification of subsequent measurement at cost would flow from consideration of (for example) a retailer's business model, and therefore also an investor's valuation model for a retailer. In that context, the primary purpose of accrual accounting for inventory is to understand the gross profit margin earned by the business, which makes the appropriate unit of account the aggregation of costs directly attributable to the inventory (Edwards and Bell, 1961; Dichev, 2008; Penman, 2009; Waymire, 2009; Barker, 2015). If the basic assumption is that the resources spent on inventory will be recovered from future sales and that the cost of goods sold measures the inventory resources consumed when a sale is made, this leads quite naturally to the practice embedded in IAS 2. The "lower of cost and market" is another way of describing the impairment overlay that tests the cost recovery assumption.

We are not advocating that the Framework should be developed to justify current practice, but when accounting practice evolves into a steady state it can be helpful to understand the principles and concepts that underpin that practice (Watts, 2003; Basu and Waymire, 2006). In this regard, the Framework's asset recognition criteria are necessary but not sufficient to determine accounting policy choice, and the Framework's discussion of measurement is thereby also incomplete.

\footnotetext{
${ }^{8}$ IASB (2018) paragraph 6.55
} 
This leads naturally to asking what information about inventory transactions would be helpful to the users of the financial statements. Would recognising the amounts management expects to sell the inventory for be helpful? Or is information about the cost of the inventory consumed more helpful? The latter begs the question as to whether actual, average or marginal cost is a better measure of consumption (Horngren and Sorter, 1961). However, the purpose of our paper is not to answer those questions, but to suggest that they are at the heart of determining the purpose of the financial statements and that answering them and embedding them in the Framework will help the IASB to develop Standards.

\section{Implications for the Unit of Account}

This discussion of cost-based measures points to a limitation in the Framework. The Framework defines the elements of the financial statements, not least assets and liabilities. It then proceeds directly to issues of recognition of the elements, focusing directly on the measurement of assets and liabilities. The absence of a discussion of the direct measurement of income or expenses is a gap in the Framework's analysis of measurement. Many measures that the Framework would characterise as being cost-based rely on assumptions about the consumption of an asset or the satisfaction of a contract (i.e. meeting an obligation). These accruals are often intended to capture some aspects of the value creation process, such as the service potential of an asset consumed during a period, the cost of inventories sold or the contracted obligations that have been satisfied. When an income (or flow) focused measure is given primacy in a Standard it is important to understand what the resulting asset or liability represents.

To illustrate this point, consider the example of accounting for a building. The Framework directs us to think about the attributes of the building, in terms of their correspondence with the generation of future economic benefits. This lends itself to thinking of the building as a distinct asset, with an exit value; most obviously (and in the spirit of Sterling, 1971), we picture fair value. And if the aim is to achieve comparability across different reporting entities, and measurement specific to the asset that is independent of the entity's intentions with respect to the asset, then we arrive at fair value excluding transactions costs. Alternatively, we could picture making the measurement more entityspecific and decision-relevant by measurement at net realisable value, which is fair value less transactions costs required to sell (Whittington, 2008 and 2017).

None of this, of course, comes close to a general description of how we actually account for buildings. In practice, IFRS makes a distinction which (to over-simplify) leads to fair value measurement for a building classified as investment property (under IAS 40) and historical cost measurement for a building classified as PP\&E (under IAS 16). The difference here is between an entity-specific business use of the asset that, in essence, involves either trading in buildings or instead employing buildings as part of the infrastructure that enables the core trading activity of the business. The language in the Framework does not 'speak to' the second (and far more common) of these two business uses. The relevant question for IAS 16 is not what constitutes the attributes of 
the asset from an economic benefit perspective, but instead what 'counts' as part of the costs to be allocated in constituting the asset in the first place, and which are later expected to be 'recovered'. This is not so much a measurement question - after all, the attribute of cost is common to all of the components that might, or might not, be capitalised in the asset. Instead, the question is perhaps better described as relating to the 'unit of account'. ${ }^{9}$

The unit of account is the "right or group of rights, the obligation or the group of obligations or the group of rights and obligations, to which recognition criteria and measurement concepts are applied." ${ }^{10}$ In simpler language, it is the thing being accounted for. While the Framework does not have a fully developed section on the unit of account, it is a pervasive concept in financial reporting. To illustrate, consider the case of a self-constructed asset, whether PP\&E, inventory or capitalised development costs. In practice, several accounting standards address challenges that arise in (for example) the initial recognition of assets of this type, which are typically developed using a combination of acquired inputs and the employees and other resources of the entity. The current Standards assess which costs should be included in the unit of account that is the constructed asset. This is subtly, but importantly, different from measuring the constructed asset. To illustrate, IFRS has special requirements in IAS 23 that allocate the implicit financing costs during construction. These cannot readily be understood as 'attributes of the asset', in the sense described in the Framework; indeed, it is difficult to reconcile the concepts in the Framework with the capitalisation requirements in IAS 23. The logic of capitalisation does, however, flow naturally from the purpose of accruals being to recognise the cost of bringing the asset into a ready-for-use condition.

Alternatively stated, we do not think of the contribution of any given input to the aggregate value of the asset being constructed; instead, we are concerned with the narrower, more tractable, question of whether or not the cost was necessarily incurred in order for the asset to be constructed. In general, the Standards distinguish between costs associated with getting an asset into a state of readiness and those costs that are instead expensed (Ijiri, 1975; Waymire, 2009). Generally, a constructed asset will have been tested and tuned prior to acquisition, which is why an asset that is tested and tuned and ready to go has greater accumulated cost than one that is not. This approach places more emphasis on constituting the thing being accounted for - the unit of account - and not on the appropriate measurement attribute.

Having established an initial measurement amount, the generally accepted accounting practice for PP\&E that has survived for more than a century (Basu and Waymire, 2006) is to estimate and allocate consumption in some way over the asset's useful life (the period of consumption). This is

\footnotetext{
${ }^{9}$ In economics the term unit of account means a nominal monetary unit of measure or currency used to value or cost an economic item. In contrast, the IASB uses the term to describe the item being measured. This paper uses the term with the meaning ascribed by the IASB, to be consistent with how it is used in the Framework.

${ }^{10}$ IASB (2018), paragraph 4.48
} 
the basic depreciation process. With perfect foresight, the total consumption expense will lead to the carrying amount of the asset being equal to the amount that the asset will be exchanged for at the time of disposal. Again, this approach relies on the underlying assumption that the resources expended will be recovered through the use of the asset. There is an impairment overlay which challenges this assumption.

The current framework does not provide guidance on what pattern of consumption the depreciation process should reflect. ${ }^{11}$ Should it set out to provide an estimate in the change in value of the asset in a given period, or should it measure consumption on some other basis? Some accelerated depreciation models are designed to mimic fair value changes by recognising a larger expense in earlier periods. In contrast, straight-line depreciation measures the consumption of service capability which is assumed to be stable over the period of consumption. The total depreciation will be unaffected by the pattern, it is the timing of the expense that changes. The Framework is silent on this issue, yet periodicity is fundamental to financial reporting. ${ }^{12}$

There are similar issues arising in accounting for research and development. The current requirements address when costs should be recognised as expenses and when they should be recognised as an asset. The intangible assets are not generally being exchanged for cash, so relying on a cash-conversion attribute to justify measuring intangible assets at a current value will not be sufficient. Biondi and Rebérioux (2012) suggest that intangible assets and innovation exacerbate the information asymmetry that characterises the specific economy of an entity. They argue that firmspecific information becomes as important as market prices to gauge the past and future performance and risk of the ongoing business firm and conclude that there is a case for improved historical cost accounting systems. The question is whether it is more helpful to investors to recognise the accruals that measure the effort an entity puts into creating intangible assets and generating revenue from them or accruals that measure the changes in value of intangibles.

Notice here a difference that emerges between accruals applied to the accumulation of cost and those designed to track changes in value. For the former, all transactions costs incurred to acquire the asset form part of the unit of account. For the latter, it is instead expected transactions costs required to realise the value of the asset that form part of the unit of account. The change in conceptualisation of the unit of account arises according to the purpose for which the asset is held, and the associated accounting design question of when the purpose of accruals should switch from measuring entry value to exit value; this is an issue of subsequent measurement rather than of measurement at initial recognition.

\footnotetext{
${ }^{11}$ See Baxter (1971) on alternative conceptualisations of depreciation.

${ }^{12}$ The use of accruals requires preparers to make assumptions about how they will recover the carrying amount from their future activities. The assumptions for long-lived assets include the period over which they expect to use the asset and the amount they expect to receive or recover when the asset has reached the end of its useful life. Several accounting Standards focus on those assumptions.
} 


\section{Implications for Initial Measurement}

This discussion of the appropriate measurement basis points to a further limitation that results from the Framework being anchored conceptually in the balance sheet. It is argued in the Framework that initial measurement and subsequent measurement cannot be considered separately. "If the initial measurement basis is inconsistent with the subsequent measurement basis, income and expenses might be recognised at the time of the subsequent measurement basis solely because of the change in measurement basis. ${ }^{13}$ It is therefore argued that recognising such income or expenses might appear to depict a transaction or other event when, in fact, no such transaction or event has occurred. Hence, the choice of measurement basis for an asset or a liability and the related income or expenses is determined by considering both the initial measurement and the subsequent measurement. Here, the IASB asserts that the initial measurement, or entry value, of an asset or liability should depend on how it is measured subsequently. If a cost basis is used subsequently then the initial measurement is historical cost.

For any given transaction, however, the cost of a discrete asset (or liability) is the entry price to the acquirer, which is the exit price to the seller. If there is then a difference for the acquiring entity between its entry and exit price for the asset, it is because that entity has access to different markets. For example, the essence of a simple retail business can be described as buying in bulk and selling (at higher prices) in individual units. In this case, the unit of account for its purchase is the bulk order. The retailer is then selling to a different market from the one in which it made the acquisition. The total fair value of the inventory to the retailer could differ from its entry price because the retailer will be measuring a different asset, with reference to a different market. These differences only happen after the entity has control of the thing being recognised. Prices can change more generally, independently of the entity. However, at least some of the differences between the entry price and the ultimate exit price(s) are likely to be attributable to the actions, or attributes, of the entity after they have control of an asset (or responsibility for a liability), reflecting their business model and market position. They should therefore be reflected in any subsequent measurement. Similarly, how an asset is used in the business should affect how it is consumed or transformed. It is the consequences of those changes that accounting is seeking to measure.

The IASB's Financial Instruments Standards, IFRS 9 and IAS 39, both require that financial instruments be measured initially at fair value. Presumably, if there is a difference between the price an entity paid for a financial instrument and its fair value in an orderly transaction, it is because the entity has access to a different market. In practical terms, an entity will report the same total difference between the transaction price and the fair value at the first reporting period whether it is separated into the difference on initial recognition and the subsequent movement or simply as the

${ }^{13}$ IASB (2018), paragraph 6.48 
difference between transaction price and fair value. We see no benefit in having different measurement bases for the initial measurement. ${ }^{14}$

Yet the way in which cost is defined in the Framework means that it is likely to be different from fair value initially. The IASB defines the historical cost of an asset as "the value of the costs incurred in acquiring or creating the asset, comprising the consideration paid to acquire or create the asset plus transaction costs." ${ }^{15}$ In contrast, if the asset is to be measured after initial recognition at fair value the entry value will be measured at fair value, which by definition in IFRS 13 excludes transaction costs. Hence, there could be a difference in the entry value the IASB attributes to an asset because of the way the IASB defines the measurement attribute. We think the difference set out by the IASB is actually better understood as a difference in unit of account.

We would measure the item initially at the transaction price even if the transaction takes place at an amount that does not reflect a fair exchange, such as can happen in common-control and other related-party transactions. The appropriate question to ask is how the circumstances in which the prices was set should affect how we think about the information the transaction amount provides. For example, if an entity buys an operating asset from a related party at a price that is clearly below a normal market value, should the acquirer recognise that asset initially at that transaction amount or be required to reset it to a current value? Recognising the item at the amount of the transaction is consistent with capturing entity-specific information. If an entity is able to gain control of an asset at a favourable price, it is likely to benefit from that advantage in future periods. The cost of consumption will be lower than if it had paid a market price for the asset. On the other hand, resetting the price on initial recognition provides information about the economic resources being used by the entity. Similarly, the initial measurement of a self-constructed asset will typically differ from the amount that would be paid if the asset was acquired in a completed state. If two assets cost different amounts because one was constructed and one was acquired in a completed state but generate the same cash flows, the accounting returns will differ over the periods these assets generate cash flows. It is valid to consider whether investors are best served by resetting the carrying amount of the assets on initial recognition to a current value (such as fair value) or allowing the differences in the returns to be reported over the life of the assets.

\section{Accruals in the Balance sheet}

There will, of course, be circumstances when current-value focused accruals will provide better information to the primary users than cost-based accruals. One of the primary factors is how the asset or liability contributes to future cash flows. Implicit in several current Standards is that

\footnotetext{
${ }^{14}$ It would be interesting to examine the extent to which entities recognise gains or losses on initial recognition of financial instruments that are subsequently measured at amortised cost. If such cases do not happen in practice, this exception to transaction-based initial measurement is redundant.

${ }^{15}$ IASB (2018), paragraph 6.5
} 
measuring particular assets or liabilities at current values is presumed by the IASB to provide better information about the cash flows that these assets will contribute to (or liabilities will take from) the entity than cost-based measures. The changes in the current values are the accruals and the income and expense amounts are a consequence of the value change. In developing its financial instruments requirements the IASB developed measurement requirements that reflected how those assets and liabilities would be converted to cash. A cost-based measure is used for financial assets where the entity expects to collect simple interest and principal. In other cases the instruments are measured at fair value. Even though fair value is designed to capture a market-participant perspective, entityspecificity is also important in determining accounting method because it is the entity's business model that leads to the selection of fair value rather than cost.

There are other reasons that the IASB might consider it appropriate to depart from a cost-based measure. Land, for example, is generally not consumed, and updating the value of land might be justified on that basis. Similarly, assets that are held for their change in value, such as investment properties or art, might be better measured at a current value.

In addition, it is sometimes the case that the cost of an asset or liability is more difficult to measure than a current value. The IASB's Standard on agricultural activities is, essentially, an inventory standard. Unlike IAS 2, however, it requires biological assets to be measured at fair value. Activities such as agriculture have a special challenge, because the produce goes through a biological process. That process causes the unit of account to change through the natural processes, such as the volume of wood in a commercial forest, growth in grapes or palm oil flowers. This can also add difficulty to measuring cost. It is inherently difficult to measure the cost of, for example a lamb or calf. It is the combination of a changing unit of account and cost attribution challenges that might warrant departing from a transaction-based measure. This might be justified because of the difficulties in measuring cost or because of the informational benefits of a current value measure. With agricultural activities, much of the debate about the current requirements has focused on whether it is helpful to separate the agricultural produce from the bearer plants, and the plants from the land in which they grow. These are unit of account issues, concerned with deciding which attributes to separate or aggregate, and therefore with how to apply accruals accounting.

\section{Summary}

By developing a framework that focuses solely on measuring assets and liabilities, with income and expenses being only a consequence of this measurement, the IASB presumptively makes current value the appropriate measurement attribute. Such an approach makes it incumbent on the IASB to justify moving from accruals that use current values to accruals that use cost-based measures. The absence of any meaningful discussion in the Framework on the purpose of the income statement and the information content in cost-based accruals make it challenging for the IASB to rebut the presumption of current-value accounting. 
If the Framework instead started with a presumption that an entity should measure transactions initially at the transaction price, we suspect that it would be more intuitive to then discuss what type of accruals are likely to provide the most helpful information to the primary users. It is here that the business model has a role in determining what information is likely to be helpful to investors, which therefore helps the IASB determine the accruals that best provide that information. Current-value accruals would simply be one of the options available to the IASB. The IASB has justified developing requirements at the Standards level that do just that. It seems to be a natural way to think about measurement requirements. The mechanics of accrual-based double-entry are just as capable of working with income and expenses that are measured directly as they are working with assets and liabilities measured directly.

\section{Bibliography}

Barker, R. and McGeachin, A. (2013) Why is there conceptual inconsistency in accounting for liabilities in IFRS? Accounting and Business Research, 43(6): 579-604.

Barker, R. (2015 Conservatism, prudence and the IASB's conceptual framework. Accounting and Business Research 45(4): 514-538.

Barker, R. and Penman, S. (2018) Moving the Conceptual Framework Forward: Accounting for Uncertainty. Contemporary Accounting Research (forthcoming).

Barth, M. (2014) Measurement in Financial Reporting: The Need for Concepts. Accounting Horizons, 28(2) 331-352

Basu, S. and Waymire G. (2006) Recordkeeping and human evolution. Accounting Horizons 20 (3): 201-229.

Basu, S., \& Waymire, G. (2008) Has the importance of intangibles really grown? And if so, why? Accounting and Business Research, 38:3, pp 171-190.

Basu, S., and G. Waymire. (2010) Sprouse's what-you-may-call-its: Fundamental insight or monumental mistake? Accounting Historians Journal 37 (1): 121-148.

Baxter, W. (1971) Depreciation. London: Sweet \& Maxwell.

Biondi, Y. and Rebérioux, A. (2012) The governance of intangibles: Rethinking financial reporting and the board of directors. Accounting Forum, Vol 36 (4): 279-293

Biondi, Y, Glover, J, Jamal, K., Ohlson, J., Penman, S., Sunder, S. and Tsujiyama, E. (2012) Some conceptual tensions in financial reporting. Accounting Horizons, 26(1), p.125-129.

Black F. (1980) The magic in earnings: Economic earnings versus accounting earnings. Financial Analysts Journal 36 (6): 19-24.

Bullen, H. and Crook, K. (2005) Revisiting the Concepts. London and Norwalk, CT: IASB and FASB.

Dichev, I. (2008) On the balance sheet-based model for financial reporting. Accounting Horizons 22(4): 453-470. 
Easton, P., Harris, T. and Ohlson, J. (1992) Aggregate accounting earnings can explain most of security returns: the case of long return intervals, Journal of Accounting and Economics, Vol.15(2-3), p.119(24)

Edwards, E.O. and P.W. Bell, 1961. The Theory and Measurement of Business Income, University of California Press.

FASB, Concepts Statement 1 (1980). Norwalk, CT: FASB.

Horngren, C., and G. Sorter. (1961) Direct costing for external reporting. The Accounting Review 36 (1): 84-93.

IASB, (2010) Conceptual Framework for Financial Reporting

IASB (2018) Conceptual Framework for Financial Reporting

Ijiri, Y. (1975) Theory of accounting measurement. Sarasota, FL: American Accounting Association.

Lev, B, S, Bharat and T. Sougiannis, (2005) R\&D Reporting Biases and Their Consequences. Contemporary Accounting Research 22(4): 977-1026.

Lev, B. and Gu, F. (2016). The End of Accounting. Hoboken, New Jersey: Wiley.

Macve, R. (2010) Conceptual frameworks of accounting: some brief reflections on theory and practice. Accounting and Business Research, 40(3), 303-308.

Marshall, R. and Lennard, A. (2016) The reporting of income and expenses and the choice of measurement bases. Accounting Horizons 30 (4): 499-510.

Nelson, M., Elliott, J., Tarpley, R. (2002) Evidence from auditors about managers' and auditors' earnings management decisions, Accounting Review, p.175 (28)

Ocean Tomo LLC (2016) Annual Study of Intangible Asset Market Value

Ohlson, J. (1991) The theory of value and earnings, and an introduction to the Ball-Brown analysis, Contemporary Accounting Research, 8(1): 1-19

Peasnell, K. (1982) Some formal connections between economic values and yields and accounting numbers. Journal of Business Finance \& Accounting 9 (3): 361-381.

Penman, S. (2009) Accounting for intangible assets: There is also an income statement. Abacus 45 (3): 359-371.

Penman, S. (2007) Financial reporting quality: is fair value a plus or a minus? Accounting and Business Research, 37(1): 33-44.

Sloan, R. (1996) Do Stock Prices Fully Reflect Information in Accruals and Cash Flows about Future Earnings? Accounting Review, 71(3): 289-315.

Sprouse, R. (1966) Accounting for what-you-may-call-its. Journal of Accountancy 122 (4): 45-53.

Sterling, R., (1970) Theory of the Measurement of Enterprise Income. Lawrence, KA: University of Kansas Press.

Stevenson, K. (2013) Rethinking the Path from an Objective of Economic Decision Making to a Disclosure and Presentation Framework, AASB Essay 2013-1. Melbourne, Australia: AASB Research Centre

Storey, R. and Storey, S. (1998) FASB special report, the framework of financial accounting concepts and standards. Norwalk, CT: FASB. 
Watts, R., (2003). Conservatism in accounting Part I: Explanations and implications, Accounting Horizons, 17, 207-221.

Waymire, G. (2009) Exchange Guidance is the Fundamental Demand for Accounting. The Accounting Review, 84(1): 53-62.

Whittington, G. (2008) Fair value and the IASB/FASB conceptual framework project: an alternative view. Abacus, 44(2), 139-168.

Whittington, G. (2015) Measurement in Financial Reporting: Half a Century of Research and Practice. Abacus 51(4).

Whittington, G. (2017) Value and Profit. Cambridge: Cambridge University Press.

Zimmerman, A., and R. Bloom. (2016) The matching principle revisited. Accounting Historians Journal 43 (1): 79-119. 
Table 1 - Accrual characterisation of IFRS requirements

\begin{tabular}{|c|c|}
\hline \multicolumn{2}{|l|}{ Income Statement focused } \\
\hline Standard & Analysis \\
\hline IAS 2 Inventories & $\begin{array}{l}\text { Inventory is measured initially at cost. When inventories are sold, the carrying } \\
\text { amount of those inventories is recognised as an expense, using either the specific } \\
\text { cost or a cost formula. }\end{array}$ \\
\hline $\begin{array}{l}\text { IAS } 16 \text { Property, Plant and } \\
\text { Equipment }\end{array}$ & $\begin{array}{l}\text { Under the cost model, PP\&E is measured initially at cost. The subsequent carrying } \\
\text { amount is calculated by deducting accumulated depreciation, which is the } \\
\text { systematic allocation of the depreciable amount of an asset over its useful life. }\end{array}$ \\
\hline $\begin{array}{l}\text { IAS } 28 \text { Investments in Associates } \\
\text { and Joint Ventures }\end{array}$ & $\begin{array}{l}\text { The equity method requires the investment to be measured initially at cost and } \\
\text { adjusted thereafter for the post-acquisition change in the investor's share of the } \\
\text { investee's net assets. }\end{array}$ \\
\hline IAS 38 Intangible Assets & $\begin{array}{l}\text { Intangible assets are measured initially at cost and either amortised systematically } \\
\text { or subjected to an impairment test if they have an indefinite life. The subsequent } \\
\text { carrying amount is cost or cost less accumulated amortisation. }\end{array}$ \\
\hline IAS 40 Investment Property & $\begin{array}{l}\text { Investment properties are required to be measured initially at cost, including } \\
\text { transaction costs. One of the choices available is to apply IAS } 16 \text { and depreciate } \\
\text { the property. }\end{array}$ \\
\hline IFRS 9 Financial Instruments & $\begin{array}{l}\text { Financial assets with contractual terms that give rise on specified dates to cash } \\
\text { flows that are solely payments of principal and interest are classified according to } \\
\text { the objective of the business model of the entity. If they are held solely to collect } \\
\text { the principal and interest they are measured at amortised cost. } \\
\text { Financial liabilities are, generally, measured at amortised cost. }\end{array}$ \\
\hline $\begin{array}{l}\text { IFRS } 15 \text { Revenue from Contracts } \\
\text { with Customers }\end{array}$ & $\begin{array}{l}\text { Contracts are measured initially at the contract (transaction) price, which is } \\
\text { allocated to components in the contract. The allocated amounts are recognised as } \\
\text { revenue as control passes to the customer, either at discrete points or over the } \\
\text { period of the contract. The remaining obligation to the customer is adjusted by } \\
\text { the amount of revenue recognised. }\end{array}$ \\
\hline IFRS 16 Leases & $\begin{array}{l}\text { The right-of-use asset and liability are measured initially at the present value of } \\
\text { the lease payments. The liability is subsequently measured at amortised cost and } \\
\text { IAS } 16 \text { is applied to the right-of-use asset. }\end{array}$ \\
\hline \multicolumn{2}{|l|}{ Balance sheet focused } \\
\hline Standard & Analysis \\
\hline $\begin{array}{l}\text { IAS } 16 \text { Property, Plant and } \\
\text { Equipment }\end{array}$ & $\begin{array}{l}\text { An entity may elect to measure PP\&E at fair value, although the PP\&E is } \\
\text { depreciated between each valuation, making it a mixed approach. }\end{array}$ \\
\hline IAS 19 Employee Benefits & $\begin{array}{l}\text { The net defined benefit plan obligation (or asset) is the net of the present value of } \\
\text { obligations under the defined benefit plan and the fair value of the plan assets. } \\
\text { The net amount is updated annually but it does not purport to be the value of the } \\
\text { net liability or asset. }\end{array}$ \\
\hline $\begin{array}{l}\text { IAS } 28 \text { Investments in Associates } \\
\text { and Joint Ventures }\end{array}$ & $\begin{array}{l}\text { Some entities are permitted to elect to measure an investment in an associate at } \\
\text { fair value. }\end{array}$ \\
\hline $\begin{array}{l}\text { IAS } 37 \text { Provisions, Contingent } \\
\text { Liabilities and Contingent Assets }\end{array}$ & $\begin{array}{l}\text { Provisions are measured at the expenditure required to settle the present } \\
\text { obligation, at the end of the reporting period (a settlement value). }\end{array}$ \\
\hline IAS 38 Intangible Assets & $\begin{array}{l}\text { Intangible assets can be measured at fair value if there is an active market, such as } \\
\text { some production quotas or licences. }\end{array}$ \\
\hline IAS 40 Investment Property & $\begin{array}{l}\text { After initial measurement at cost, one of the choices available to entities is to } \\
\text { measure investment properties at fair value at each reporting date. }\end{array}$ \\
\hline IAS 41 Agriculture & $\begin{array}{l}\text { All biological assets are measured at fair value less costs to sell, unless fair value } \\
\text { cannot be measured reliably. }\end{array}$ \\
\hline IFRS 9 Financial Instruments & Financial assets not measured at amortised cost are measured at fair value. \\
\hline
\end{tabular}


Table 1 - Accrual characterisation of IFRS requirements

\begin{tabular}{|c|c|}
\hline & $\begin{array}{l}\text { Financial liabilities held for trading are measured at fair value. An entity may also } \\
\text { elect to measure a financial liability at fair value if it meets specified criteria. } \\
\text { Equity investments are measured at fair value. }\end{array}$ \\
\hline \multicolumn{2}{|l|}{ Other } \\
\hline IAS 12 Income Taxes & $\begin{array}{l}\text { Captures differences between accounting and tax assets and liabilities, which gives } \\
\text { it a balance sheet focus. However, the net deferred tax asset or liability reflects } \\
\text { the nature of the differences and does not purport to reflect any particular value. }\end{array}$ \\
\hline $\begin{array}{l}\text { IFRS } 5 \text { Non-current Assets Held } \\
\text { for Sale and Discontinued } \\
\text { Operations }\end{array}$ & $\begin{array}{l}\text { Non-current assets 'held for sale' are measured at the lower of the carrying } \\
\text { amount and fair value less costs to sell. The non-current assets are no longer } \\
\text { depreciated. Hence, they are only adjusted from the carrying amount down to fair } \\
\text { value less costs to sell, and not upwards. }\end{array}$ \\
\hline Initial measurement & $\begin{array}{l}\text { Several Standards require assets or liabilities to be measured initially at fair value. } \\
\text { However, in many cases this because a transaction price for the specific asset or } \\
\text { liability is not available or observable and the fair value is a proxy for the entry } \\
\text { price. That fair value is then deemed to be the cost, such as in IFRS } 3 \text { Business } \\
\text { Combinations and IAS } 16 \text { for assets acquired in a non-monetary exchange. } \\
\text { IFRS } 2 \text { sets out the initial measurement of transactions in which an entity uses its } \\
\text { equity instruments as consideration for goods or services. The transactions are } \\
\text { measured using the fair value of the goods or services received, unless they are } \\
\text { transactions with employees. In the latter case the transaction is measured using } \\
\text { the fair value of the equity instruments granted, because it is typically not possible } \\
\text { to estimate reliably the fair value of employee services received. }\end{array}$ \\
\hline $\begin{array}{l}\text { Impairment (IAS } 36 \text { Impairment } \\
\text { of Assets) }\end{array}$ & $\begin{array}{l}\text { The purpose of the Standard is to test the assumption that the carrying amount of } \\
\text { an asset measured from an income statement focused requirement will be } \\
\text { recovered. If there is an impairment it effectively "re-sets" the cost down to the } \\
\text { "recoverable amount" (which is the higher of the fair value and its value in use). }\end{array}$ \\
\hline
\end{tabular}

